\title{
SchussenAktivplus: reduction of micropollutants and of potentially pathogenic bacteria for further water quality improvement of the river Schussen, a tributary of Lake Constance, Germany
}

\author{
Rita Triebskorn ${ }^{1 *}$, Klaus Amler², Ludek Blaha ${ }^{3}$, Claudia Gallert $^{4}$, Sabrina Giebner ${ }^{5}$, Hans Güde ${ }^{6}$, Anja Henneberg ${ }^{1}$, \\ Stefanie Hess ${ }^{7}$, Harald Hetzenauer ${ }^{6}$, Klaus Jedele ${ }^{8}$, Ralph-Michael Jung ${ }^{9}$, Sven Kneipp ${ }^{10}$, Heinz-R Köhler ${ }^{1}$, \\ Stefanie Krais ${ }^{1}$, Bertram Kuch ${ }^{11}$, Claudia Lange ${ }^{11}$, Herbert Löffler ${ }^{6}$, Diana Maier ${ }^{1}$, Jörg Metzger ${ }^{11}$, Michael Müller ${ }^{8}$, \\ Jörg Oehlmann ${ }^{5}$, Raphaela Osterauer ${ }^{1}$, Katharina Peschke ${ }^{1}$, Jürgen Raizner ${ }^{12}$, Peter Rey ${ }^{13}$, Magali Rault ${ }^{14}$, \\ Doreen Richter ${ }^{15}$, Frank Sacher ${ }^{15}$, Marco Scheurer ${ }^{15}$, Jutta Schneider-Rapp ${ }^{2}$, Merav Seifan ${ }^{16}$, Markus Spieth ${ }^{17}$, \\ Hans-Joachim Vogel ${ }^{18}$, Michael Weyhmüller ${ }^{19}$, Josef Winter ${ }^{7}$ and Karl Wurm ${ }^{20}$
}

\begin{abstract}
The project focuses on the efficiency of combined technologies to reduce the release of micropollutants and bacteria into surface waters via sewage treatment plants of different size and via stormwater overflow basins of different types. As a model river in a highly populated catchment area, the river Schussen and, as a control, the river Argen, two tributaries of Lake Constance, Southern Germany, are under investigation in this project. The efficiency of the different cleaning technologies is monitored by a wide range of exposure and effect analyses including chemical and microbiological techniques as well as effect studies ranging from molecules to communities.
\end{abstract}

\section{Background}

According to the European Water Framework Directive, a "good ecological and chemical status of surface waters" has to be achieved by 2015 . In the context of this requirement, the release of micropollutants and pathogens into surface waters via wastewater treatment plants (WWTPs) has come into the focus of scientists as well as of politicians. Concomitantly, several research projects, as e.g. the EU project "Poseidon" [1], the Swiss project "Strategy Micropoll" [2] or long-term activities of NORMAN network (http://www.norman-network.net/) have investigated the efficiency of different technologies in WWTPs, as e.g. ozonation or charcoal filters, to lower concentrations of micropollutants in surface waters. The efficiency and practical suitability of these technologies and their respective advantages and disadvantages were

\footnotetext{
* Correspondence: rita.triebskorn@uni-tuebingen.de

${ }^{1}$ Animal Physiological Ecology, University of Tuebingen, Konrad-Adenauer-Str. 20, Tuebingen D-72072, Germany

Full list of author information is available at the end of the article
}

assessed for example by Beier and colleagues [3]. Stalter and co-workers [4] and Schrank and colleagues [5] critically discuss the creation of toxic metabolites by ozonation and recommend always to combine ozonation with any type of filters, e.g. sand filters. As a major advantage of ozonation Abegglenand and collegues [2] and Margot and colleagues [6] stress its efficiency to reduce pathogens in addition to micropollutants.

In contrast to WWTPs, less attention has been paid up to now to storm water overflow basins (SOBs) as important sources for the release of micropollutants and bacteria into surface waters [7]. In two studies, Brunner and colleagues [8] showed the efficiency of retention soil filters for the reduction of particular and dissolved material as well as for ammonia, and Waldhoff and coworkers [9] found bacteria to be reduced by up to $90 \%$.

Up to now, an integrative approach to address simultaneously WWTP and SOBs, micropollutants and pathogens and combinations of different cleaning technologies 
to reduce their release into surface waters has not been realized so far which makes the project SchussenAktivplus highly innovative with this respect. A further outstanding advantage of this project is, in addition, that the efficiency of the applied technologies is not only checked by means of chemical and microbiological analyses but, in parallel, by a wide range of ecotoxicological and ecological effect studies ranging from the molecular to the community level. Based on this holistic approach it will be possible to establish causal relationships between exposure data, results from laboratory tests indicating toxic or endocrine potentials, and effect data in feral animals by means of plausibility chains as outlined by Triebskorn and colleagues [10].

As a model for a densely populated catchment area, the catchment area of the river Schussen, one major tributary of Lake Constance, is under investigation in this project. In total, 20 WWTPs and more than 100 SOBs are connected to this river. Recently, Triebskorn \& Hetzenauer [11] reported on relatively high micropollutant burdens of the Schussen river compared to two other tributaries of lake Constance, the Argen and the Seefelder Aach. Lake Constance itself is one of the most important drinking water reservoirs in Germany and furthermore serves as a popular recreation site and intensely used natural bathing freshwater. Consequently, minimizing the risk for man and the environment resulting from micropollutant and pathogen discharges into this ecosystem is of great public interest especially with respect to the precautionary principle.

\section{Aim of the project}

The project aims at providing a scientifically sound concept for an extended sewage and rainwater treatment in densely populated river catchment areas in view to reduce micropollutants and sanitarily relevant pathogens (including antibiotic-resistant bacteria) in surface waters. By a combination of chemical and microbiological analyses and effect-oriented biological studies which reflect consequences of the applied technologies for biota in the rivers from the molecular to the community level, the effectiveness of the applied technologies will be assessed. In addition, the optimization of assays that characterize exposure and biological effect is envisaged. Extrapolation of data on micropollutant and pathogen reduction to the entire catchment area of the river Schussen will result in scenarios whose potential for implementation will be critically assessed by a comprehensive cost-benefit analyses.

\section{Key activities}

Prior and after application of different sewage and rainwater treatment technologies (including e.g. combinations of ozonation with sand and charcoal filters) the release of micropollutants and bacteria (including antibiotic-resistant bacteria) is investigated in five different test systems (three WWTPs of different size and two SOBs). In parallel, the resulting reduction of toxic and endocrine potentials in effluents of the test systems, in stream water of the receiving water course, and its sediments are quantified at five different field sites at the Schussen river as well as at one control site at the river Argen. In addition, the putative decrease of harmful potentials in freshwater species are recorded by various biological in vitro and in vivo tests. Concomitantly, real effects of the innovative cleaning technologies are traced in the ecosystem by effect analyses in different indigenous fish species and benthic invertebrates that serve as their feed (Figure 1).

In parallel to the scientific progress, results and information on their implications will be actively disseminated among the public and selectively communicated to stakeholders and policy makers.

\section{Work packages (WPs)}

WP 1a: Technological improvement of wastewater treatment plants and storm water overflow basins

Jedele \& Partner GmbH, Stuttgart takes over the technical implementation of new technology, maintenance, servicing, and optimization at the following five test systems (three WWTPs and two SOBs).

Test system 1 WWTP Langwiese, Association for Sewage Treatment (AZV) Mariatal.

The WWWTP Langwiese of the AZV Mariatal is the model for a large WWTP with about 170,000 population equivalents (PE). It will be equipped with an active charcoal filter on a large scale. The installation will be finished in spring 2013. Powdered activated carbon will be added to the main flow after the biological treatment and before the contact filter.

Test system 2 WWTP Eriskirch, Association for Sewage Treatment (AV) Unteres Schussental.

With about 40,000 PE, test system 2 is a model for a medium-sized WWTP. Here, a combination of ozonation, sand filter, and granulated activated carbon filter has been realized on a semi-industrial scale, i.e. in a partial flow of the effluent.

Test system 3 WWTP Merklingen, community of Merklingen.

In test system 3, our model for a small WWTP (2400 $\mathrm{PE}$ ) ozonation has been combined with an existing slow sand filter on a large-scale.

Test system 4 Storm water overflow basin Mariatal, town of Ravensburg. 


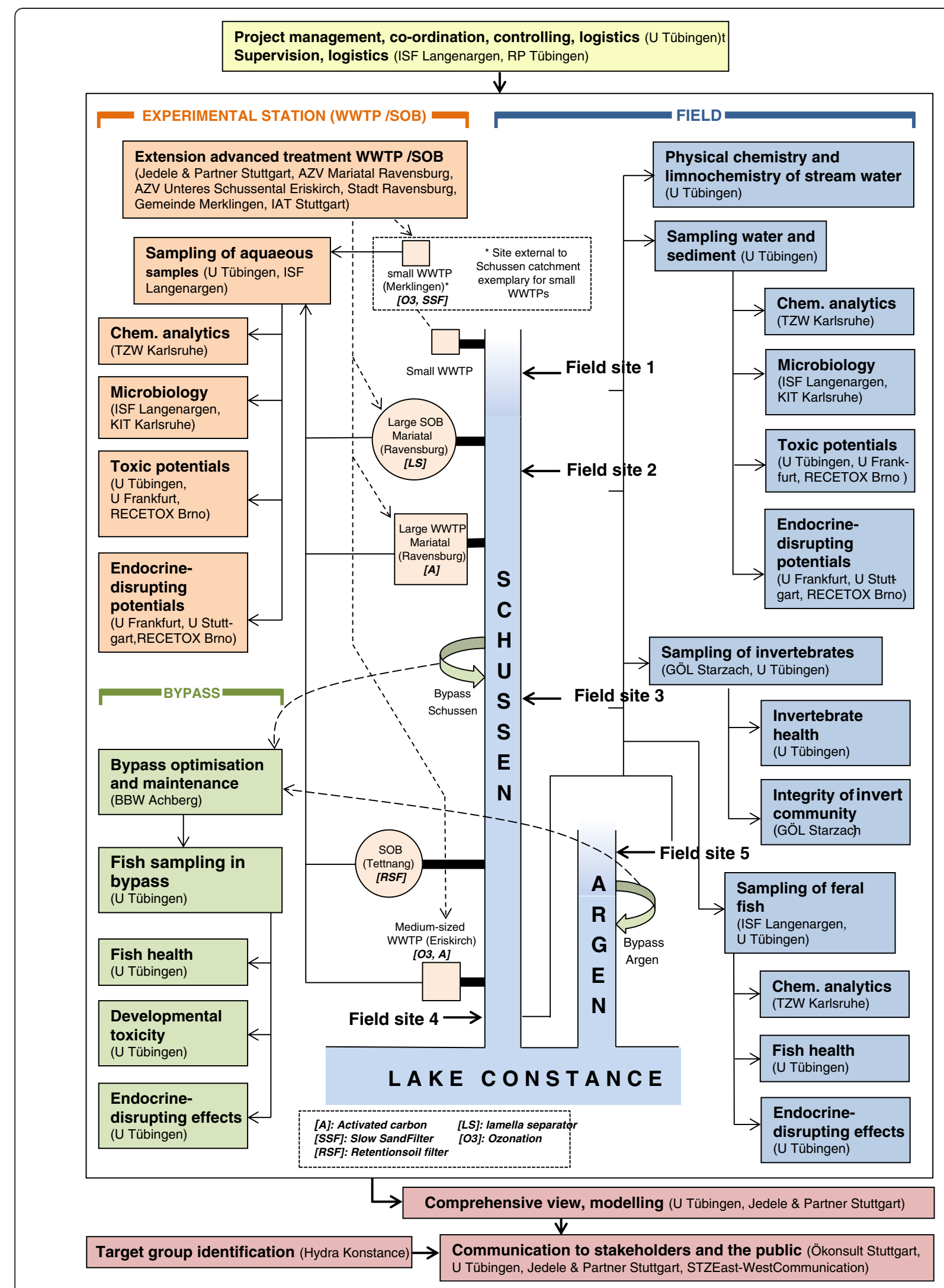

Figure 1 Summary of the project concept (WWTP: Waste Water treatment plant; SOB: Storm water Overflow basin). 
Using this test system will allow investigation on a semi-industrial scale whether the separation and retention of solids can be improved by the installation of a lamella separator.

Test system 5 Storm water overflow basin connected to a retention soil filter Tettnang, town of Tettnang. In this already existing test system the efficiency of rainwater treatment with final purification by a retention soil filter is investigated.

\section{WP 1b: Bypass systems}

At the Schussen river downstream the WWTP Langwiese and, as a control, at the river Argen, two flow-through bypass systems have been established by BBW Achberg for active monitoring purposes. These mesocosms consist of five $250 \mathrm{~L}$ aquaria each flown through by $0.4 \mathrm{~L} / \mathrm{s}$ of stream water. In each of the two systems, two aquaria can be heated up to $8^{\circ} \mathrm{C}$. In these semi-field test systems, embryo tests with trout and exposure experiments with adult trout and gammarids are performed.

\section{WP2: Chemical analyses}

The Water Technology Center, Karlsruhe (TZW) is analyzing micropollutants and heavy metals in wastewater, surface water, sediments, and fish tissue samples. Furthermore, hydrochemical water parameters are regularly recorded. Micropollutants like e.g. pharmaceuticals are analyzed by gas or liquid chromatography coupled to mass spectrometry. By combining appropriate extraction and enrichment techniques during sample pre-treatment, a high selectivity and sensitivity is achieved. The analytical techniques used for solid samples are similar to those used for water samples but require a sample preparation that efficiently removes co-extracted matrix compounds. The analysis of fish tissue samples and sediments focus on more non-polar compounds (e.g. polycyclic aromatic hydrocarbons) which are more likely to accumulate in these compartments.

A total of $>150$ micropollutants are analyzed in more than 75 water samples and 120 sediment and tissue samples. Additionally, some pharmaceuticals and the artificial sweetener acesulfame have been defined as indicator compounds with a constant discharge in recipient waters. To control the upgrading measures with sufficiently high resolution in time these indicator compounds are measured in 65 additional wastewater samples.

\section{WP3: Microbiological analyses}

The Institute for Lake Research, Langenargen (ISF) determines concentrations of fecal bacteria ( $E$. coli [EC] and intestinal enterococci [IE]) in water samples of the five tests systems as well as in surface water and sediments of the five field sites. In order to obtain directly colonies for further isolation, agar plate methods were preferred over MPN procedures with liquid media for determining concentrations of fecal bacteria. For EC quantification appropriately diluted samples are plated on ECD agar (Merck) [12]. In agreement with criteria applied in ISO EN 9508-32, colonies with glucuronidase and indole reaction aree counted as EC. Concentrations of IE are determined according to ISO EN 7899-2 by counting colonies with positive esculin reaction of isolates grown on SlanetzBartley agar. Because river sediments were shown to be potentially important intermediate storage sites of fecal bacteria, that can be mobilized after re-suspension at increasing water discharge [13], special attention is given to this aspect by testing growth, survival, and mobilization of fecal bacteria after re-suspension of selected isolates. Finally, it is attempted to estimate the effect of climate changes on the loads of fecal bacteria in the field by means of simple climate scenario models.

Antibiotic resistance is one of the most serious health threats of the $21^{\text {th }}$ century. For this reason, the spread of resistant microorganisms into the environment should be restricted. The contribution of the Institute of Biology for Engineers and Biotechnology of Wastewater, KIT Karlsruhe is to isolate, to identify and to determine the percentage of strains resistant to antibiotics in species of staphylococci, enterococci, and E. coli that are introduced into the aqueous environment by discharge of 'purified' wastewater. It will be evaluated, whether advanced treatment technologies of municipal wastewater could reduce the risk of dissemination of microorganisms, especially of antibiotic-resistant bacteria.

Distinct selective media like mannitol salt agar and Chapman-Stone agar are used to isolate staphylococci from sewage, treated sewage, and surface waters. The isolated cultures are identified at the species level by the use of physiological tests in Micronaut-Staph ${ }^{\circledR}$ microtiter plates. Antibiotic susceptibility to oxacillin, ciprofloxacin, erythromycin, and clindamycin is tested by the Kirby-Bauer method according to DIN 58940 [14]. The presence of the mecA-gene in methicillin/ oxacillin-resistant staphylococci, especially in S. aureus (MRSA: methicillin-resistant Staphylococcus aureus) is revealed by PCR and agarose-gel electrophoresis. In cooperation with ISF Langenargen, isolated fecal indicator organisms are identified and antibiotic susceptibility against $\beta$-lactam antibiotics (ESBL: extended-spectrum $ß$-lactamase), ciprofloxacin, and sulfamethoxazol/trimethoprim are tested with E. coli isolates. Antibiotic susceptibility against vancomycin (VRE: vancomycin-resistant enterococci) and ampicillin tested with enterococci-isolates are used to describe the resistance pattern of environmental species. Additionally, the presence of the respective 
antibiotic-resistance genes $\left(b l a_{\mathrm{TEM}}, b l a_{\mathrm{CTX}-\mathrm{M}}\right.$ and $v a n A-E$, $v a n G$ ) is examined.

\section{WP 4: Effect analyses}

To assess toxic and endocrine potentials in water samples from the five test systems as well as in surface water and sediments of the five field sites, several laboratory tests are applied.

These include several types of in vitro assays (e.g. reporter gene assays using yeast and vertebrate cell lines), but also in vivo laboratory tests, as e.g. the Early Life Stage-test with the zebrafish Danio rerio or the growth inhibition tests with Lumbriculus variegatus or Lemna minor. The reporter gene bioassays are based on genetically modified cell lines, which have been stably transfected with specific reporter genes (e.g. firefly luciferase). Reporter genes are induced and translated in the presence of specifically acting compounds (e.g. estrogens, androgens etc.), and the enzymatic activity of the reporter protein is easily determined (e.g. measuring bioluminescence). The detection of antagonistic activity requires a background concentration of the agonistic reference substance and, hence, antagonistic activity in the sample leads to a reduced expression and activity of the reporter enzyme (i.e. decrease in luminescence or color change). This battery of bioassays therefore provides a comprehensive overview of the overall toxicity of the test samples (e.g. surface water, effluent or sediment).

Toxic and endocrine effects, in contrast, are investigated in vivo either in feral fish (chub [Leuciscus cephalus], spirlin [Alburnoides bipunctatus]), and gammarids directly taken from the field, or in animals (trout [Salmo trutta $f$. fario, Oncorhynchus mykiss]and gammarids) exposed to the river water in the flow-through bypass systems under semi-field conditions.

Tests indicating either toxic or endocrine potentials and effects are summarized in Table 1.

\section{Toxic potential and effects Genotoxicity}

Possible genotoxic effects of concentrated samples are determined by the University of Frankfurt/Main with bacterial tests like the $u m u$ - test and Ames fluctuation bioassay using Salmonella typhimurium [15,16]. The $u m u$ - assay is a so-called indicator test due to the fact that it detects primary DNA damage. In contrast, the Ames micro-suspension bioassay measures base substitution and frameshift mutagenesis. In addition, the $\boldsymbol{U n \boldsymbol { i }}$ versity of Tuebingen investigates genotoxicity in vivo by means of the micronucleus test in erythrocytes of fish.

\section{Proteotoxicity}

At the University of Tuebingen, stress proteins are under investigation in fish tissues and gammarids sampled at the Schussen and the Argen at four field sites or exposed in the bypass systems as a biomarker of toxic effect related to proteotoxicity [17]. To quantify levels of the $70 \mathrm{kD}$ stress protein family (Hsp70), a quantitative immunoblotting procedure using SDS-gel electrophoresis and monoclonal antibodies in reference to total protein and an internal Hsp70 standard [18] is used. Hsp70 levels are determined in liver, kidney, gills, and gonads of two indigenous fish species, chub and spirlin, as well as in trout exposed in the bypass systems.

\section{Dioxin-like toxicity}

By RECETOX, Brno, dioxin-like toxicity in vitro is investigated using a rat hepatoma cell line H4IIE.luc, which determines dioxin-like action (generated by e.g. PCBs, dioxins, polycyclic aromatic hydrocarbons etc.) by measuring luciferase activity under the control of the arylhydrocarbon receptor (AhR ) [19] . In parallel, at the University of Frankfurt/Main agonistic activity at the aryl-hydrocarbon receptor is examined with a yeastbased bioassay [20]. In vivo, AhR-mediated effects are in the focus of CYPIA1 measurements in liver and gill samples of chub and trout. The EROD activity, which is photometrically determined at the University of Tuebingen according to [21], reflects the cytochrome P450IA1 biotransformation activity in these respective organs.

\section{Phytotoxicity}

As an in vivo toxicity test indicating phytotoxicity in samples of the five test systems, river surface water, and sediments, the University of Frankfurt makes use of the Lemna minor growth inhibition test according to OECD [22].

\section{Neurotoxicity}

With respect to impact of neural function, one enzyme group of interest are cholinesterases including acetylcholinesterases (ACHE). Fish brain exhibits ACHE activity involved in the deactivation of acetylcholin at nerve endings, preventing continuous neuronal firing, which is essential for normal functioning of sensory and neuromuscular systems. Many organophosphate and carbamate pesticides are reported to be effective ACHE inhibitors [23]. Activity measurements of ACHE are carried out spectrophotometrically on fish brain extracts at the University of Avignon according to [24] in cooperation with the University of Tuebingen.

\section{Cytotoxicity / tissue impairment}

To evaluate the degree in reducing non-specific toxicity by the new wastewater treatment technologies, two cytotoxicity assays using vertebrate cell lines (a rat pituitary and a rainbow trout liver cell line) are applied by the 
Table 1 Summary of bio-assays and biotests used in SchussenAktivplus

\begin{tabular}{|c|c|}
\hline Indication level & Test \\
\hline \multirow[t]{6}{*}{ Toxic potentials } & umu-test, Ames test (genotoxicity) \\
\hline & in vitro reporter gene assays (vertebrate cells, yeasts) controlled by Ah-receptor (dioxin-like toxicity) \\
\hline & GH3, RTL-W1-cell culture (cytotoxicity) \\
\hline & ELS-tests with zebrafish (developmental toxicity) \\
\hline & Growth inhibition test with Lumbriculus variegatus (developmental toxicity) \\
\hline & Growth inhibition test with Lemna minor (phytotoxicity) \\
\hline \multirow[t]{7}{*}{ Toxic effects } & Early life stage tests with trout (developmental toxicity) \\
\hline & Acetylcholinesterase inhibition in the fish brain (neurotoxicity) \\
\hline & Cytochrome P450IA1 (EROD) in fish liver and gills (dioxin-like toxicity) \\
\hline & Histopathology of fish liver, gills, and kidney and gammarid tissues (cytotoxicity, fish and invertebrate health) \\
\hline & Stress protein Hsp 70 (proteotoxicity) \\
\hline & Micronucleus test in fish blood cells (genotoxicity) \\
\hline & Macrozoobenthos community (community integrity) \\
\hline \multirow[t]{3}{*}{ Endocrine potentials } & E-Screen (estrogenicity) \\
\hline & Reporter gene assays in vitro (estrogenicity, androgenicity, anti-androgenicity) \\
\hline & Reproduction test with the snail Potamopyrgus variegatus (estrogenicity) \\
\hline \multirow[t]{4}{*}{ Endocrine effects } & Vitellogenin in juvenile and male trout (estrogenicity) \\
\hline & Gonad histology of fish and gammarids, \\
\hline & Gonadosomatic index (GSI) in fish (estrogenicity, androgenicity) \\
\hline & Sex ratio and fecundity in gammarids (estrogenicity, androgenicity) \\
\hline
\end{tabular}

University of Frankfurt/Main. These cell lines were chosen because of their high sensitivity and ecological relevance. In vivo, cytotoxicity reflected by impaired tissue integrity is studied at the University of Tuebingen in feral fish (chub and spirlin) and gammarids, as well as in trout and gammarids exposed to the river water in the bypass-systems at the Schussen and Argen. In fish, the health status of liver, kidney, and gills and, in gammarids, the integrity of the hepatopancreas is described and semi-quantitatively assessed by means of a fivescaled classification protocol $[25,26]$. In addition, the degree of parasitic infestation is determined in fish and gammarids.

\section{Developmental toxicity}

In order to reveal negative impacts on the development of fish and invertebrates, at the University of Tuebingen, early life stage (ELS) tests with brown trout (Salmo trutta f. fario) and zebrafish (Danio rerio) are conducted. Tests with tout are performed according to [27] in the two bypass-systems at the river Schussen (downstream the WWTP Langwiese) and, as a reference, at the river Argen. Aquaria in the laboratory serve as negative controls. Shortly after fertilization, trout eggs get exposed to the three systems for continuous exposure. At least every second day eggs (or rather the developing embryos inside the chorion) are examined and coagulation/mortality, heart rate, hatching, swim up, and malformations are recorded. Similar endpoints of toxicity are investigated in the laboratory tests with the zebrafish according to [28]. In order to show possible impact on the development of sedimentdwelling invertebrates, the reproduction test with the blackworm Lumbriculus variegatus has been implemented into the effect-based test battery. This test is conducted at the University of Frankfurt/Main according to OECD [29].

\section{Community integrity}

By the Water Ecology Laboratory Starzach the integrity of the macrozoobenthos communities of Schussen and Argen are monitored and assessed with the multihabitat sampling method according to the EU Water Framework Directive [30]. Particular attention is paid to species residing in the sediment (e.g. oligochaetes, midge larvae) and toxicant-sensitive species, as e.g. gammarids.

\section{Endocrine potentials and effects}

RECETOX Brno determines estrogenic potentials with the human breast carcinoma cell line MVLN [31] and the cell line HeLa9903, stably transfected with a luciferase reporter gene under the control of the estrogen receptor. Androgenic and anti-androgenic potentials are investigated using reporter gene assays with the breast carcinoma cell line MDAkB [32]. At the University of Frankfurt/Main potentials for estrogenicity, anti- 
estrogenicity, androgenicity, and anti-androgenicity are detected with yeast-based bioassays [20].

At the University of Stuttgart, estrogenic potentials are determined by the E-screen assay, which is based on the proliferation of human breast carcinoma cells (MCF-7) in the presence of estrogen active substances in the samples. The estrogenic activity determined by the E-Screen reflects a sum parameter over all hormonal active substances present in the samples that is expressed in concentration units of the reference substance $17 \beta$ estradiol (17 $\beta$-estradiol equivalent concentration, EEQ). The determination limit of the test for surface waters ranges in the order of $<0.1 \mathrm{ng} / \mathrm{L}$ EEQ. The applied E-screen assay was developed by Soto and colleagues [33], optimized by Körner and co-workers [34], and modified by Schultis [35]. To determine the estrogenic activity in stream water, acidulated water samples are solid phase extracted prior to the test for their endocrine potentials in vitro.

As an in vivo laboratory test for the detection of endocrine potentials, the reproduction test with the New Zealand mudsnail Potamopyrgus antipodarum is carried out at the University of Frankfurt/Main according to OECD [36]. In these parthenogenetically reproducing snails, offspring numbers (prior and after development of a visible shell) as well as mortality are determined after exposure to samples from the five test systems and to surface water and sediment samples of the five field sites.

To detect endocrine effects in feral fish, at the University of Tuebingen the egg yolk precursor protein vitellogenin is analyzed in bypass-exposed trout. Furthermore, gonads of feral fish are examined in respect to impairment of tissue integrity, presence of hermaphroditic ovaries or testes, the gonado-somatic index (GSI), and maturity. Since vitellogenin typically is produced by breeding females only, the detection of this protein in male or juvenile fish indicates the presence of estrogenically active chemicals in the environment $[37,38]$. After exposure in the bypass-systems for about 140 days, blood samples of male fish or whole body homogenates of juveniles get analyzed with a vitellogenin ELISA test kit (Biosense; product number: V01004402-096). As a positive control, fish are exposed to $20 \mathrm{ng} / \mathrm{L} 17 \alpha$-ethinylestradiol $\left(\mathrm{EE}_{2}\right)$; as a negative control they are kept in conditioned tap water. The gonad integrity as well as the maturity stages of ovaries and testes are diagnosed microscopically, and the gonado-somatic index (GSI) in trout and chub is determined according to [39].

In order to address possible endocrine effects also in invertebrates, gammarid populations from the four field sites are under investigation with respect to sex ratio, maturity, fecundity, and gonad integrity at the University of Tuebingen. In gammarids, these endpoints have been proven sensitive endocrine-modulated reactions [40]. To determine the fecundity, breeding females are caught from the streams, eggs and juveniles in the marsupium are counted, and the fecundity index is calculated. In addition, ovaries are fixed for histology and sections are examined microscopically to determine the maturity status of the gametes.

\section{WP 5: Data analysis}

In addition to methods of conventional correlation analysis (linear/non-linear regression, ANOVA, tests of significance), an information theory approach introduced to the biological discipline by Burnham \& Anderson $[41,42]$ is used by the University of Tuebingen to identify the relative importance of exposure data on recorded effects in biota. Its goal is to select the best explanatory variable from a large set of potential factors. In this approach, variable selection takes into account multiple competing hypotheses and allows inferences through the whole set of potential models, thus takes into account the fact that no single model (i.e., variable composition) can perfectly reflect nature. The model selection approach is based on Akaike's Information Criterion (AIC). In general, this criterion is based on the estimation of information loss when a model is used to approximate the truth [43]. Using this approach, it is possible to estimate the relative precision of several models created from the same data set. Therefore, models can be ranked according to their data fit and all single factors and interactions can be estimated and predicted by model averaging.

Calculations concerning the extrapolation of data on micropollutant and pathogen reduction to the entire catchment area will be conducted by Jedele \& Partner GmbH, Stuttgart and University of Tuebingen.

\section{WP 6: Coordination and communication}

The entire project is coordinated by the University of Tuebingen supported by the Regional Commission Tuebingen. In cooperation with the University of Tuebingen Ökonsult Stuttgart is responsible for the identification of target groups and communication channels suitable for the publication of the project, connections to local press and information media and the organization of information events for stakeholders and the public. Major aims of the communication are (1) raising the awareness in the public for water protection and problems related to micropollutants and pathogen release into surface waters, (2) investigation of the readiness of the public to accept additional dues for this purpose, and (3) dissemination of the project's aims and results to the scientific community, stakeholders and the public.

Together with the University of Tuebingen and Hydra Konstanz, Ökonsult Stuttgart has already realized the homepage of the project (www.schussenaktivplus.de) and 
an information flyer which can be downloaded from the project homepage. In close cooperation with the Steinbeis Transfer Center East-West Cooperation a connection of SchussenAktivplus to the Danube strategy will be realized.

\section{Competing interests}

The authors declare that they have no competing interests.

\section{Authors' contributions}

Rita Triebskorn who is responsible for the general design of the project wrote the introductory parts of the manuscript. The other authors contributed with specific information concerning their respective methods. All authors read and approved the final manuscript.

\section{Acknowledgements}

The project SchussenAktivplus is funded by the Federal Ministry for Education and Research (BMBF) and cofounded by the Ministry of Environment Baden-Württemberg. In addition, Jedele \& Partner GmbH, Ökonsult GbR, the city of Ravensburg, the AZV Mariatal and the AV Unteres Schussental financially contribute to the project.

SchussenAktivplus is connected to the BMBF action plan "Sustainable water management (NaWaM)" and is integrated in the BMBF frame programme "Research for sustainable development FONA". It is part of the the funding measure "Risk Management of Emerging Compounds and Pathogens in the Water Cycle (RiSKWa)" introduced to the public by Huckele \& Track [44]. Contract period: 1/ 2012 to 12/2014, Funding number: 02WRS1281A-L.

\section{Author details}

${ }^{1}$ Animal Physiological Ecology, University of Tuebingen, Konrad-Adenauer-Str. 20, Tuebingen D-72072, Germany. ${ }^{2}$ Ökonsult, Gerberstr. 9, Stuttgart 70178, Germany. ${ }^{3}$ RECETOX-Research Centre for Toxic Compounds in the Environment, Faculty of Science, Masaryk University, Kamenice 3, Brno CZ-62500, Czech Republic. "Department Microbiology and Biotechnology, University of Applied Sciences Emden Leer, Constantiaplatz 4, Emden D-26723, Germany. ${ }^{5}$ Department Aquatic Ecotoxicology, Goethe University Frankfurt am Main, Max-von-Laue-Straße 13, Frankfurt am Main D-60323, Germany. ${ }^{6}$ ISF LUBW, Baden-Württemberg State Institute for the Environment, Measurement and Nature Conservation, Institute for Lake Research, Argenweg 50/1, Langenargen D-88085, Germany. 'Institute of Biology for Engineers and Biotechnology of Wastewater Treatment, Karlsruhe Institute of Technology, Am Fasanengarten, Karlsruhe D-76128, Germany. ${ }^{8}$ JuP, Dr.-Ing. Jedele und Partner GmbH, Industriestraße 2, Stuttgart D-70565, Germany. ${ }^{9}$ AZV (Wastewater treatment authority) Mariatal / City of Ravensburg, Seestr.36, Ravensburg D-88214, Germany. ${ }^{10}$ Municipality of Merklingen, Hauptstraße 31, Merklingen D-89188, Germany. ${ }^{11}$ Institute for Sanitary Engineering, Water Quality and Solid Waste Management, University of Stuttgart, Bandtäle 2, Stuttgart D-70569, Germany. ${ }^{12}$ Steinbeis Transfer Center East-West Cooperation, Kaplaneigasse 8, Deggingen D-73326, Germany. ${ }^{13}$ Hydra-Institute, Fürstenbergstr. 25, Konstanz D-78467, Germany. ${ }^{14}$ Université d'Avignon et des Pays de Vaucluse UMR 7263 CNRS-IRD, IMBE, 301 rue Baruch de Spinoza BP21239 F-84916 Avignon Cedex 09, Avignon, France. ${ }^{15}$ Water Technology Center Karlsruhe (TZW), Karlsruher Straße 84, Karlsruhe D-76139, Germany. ${ }^{16}$ Department of Plant Ecology, University of Tuebingen, Auf der Morgenstelle 3, Tuebingen D-72076, Germany. ${ }^{17} \mathrm{AV}$ Unteres Schussental, Montfortplatz 7, Tettnang D-88069, Germany. ${ }^{18}$ Regional Commission (RP) Tübingen, Konrad-Adenauerstr. 20, Tübingen D-72072, Germany. ${ }^{19}$ BBW Biology Laboratory Achberg, Am Königsbühl 15, Achberg D-88147, Germany. ${ }^{20} \mathrm{GÖL}$ Water Ecology Laboratory Starzach, Tulpenstr. 4 Starzach D-72181, Germany.

Received: 13 November 2012 Accepted: 14 November 2012 Published: 14 January 2013

\section{References}

1. Ternes T: Assessment of technologies for the removal of pharmaceuticals and personal care products in sewage and drinking water facilities to improve the indirect potable water reuse (POSEIDON); 2004. Final report EU 2004, http:// poseidon.bafg.de/servlet/is/2888/.

2. Abegglen C, Escher B, Hollender J, Koepke S, Ort C, Peter A, Siegrist H, von Gunten U, Zimmermann S, Koch M, Niederhauser P, Schärer M, Braun C,
Gälli R, Junghans M, Brocker S, Moser R, Rensch D: Ozonung von gereinigtem Abwasser. Schlussbericht Pilotversuch Regensdor: EAWAG; 2009:80.

3. Beier S, Pinnekamp J, Schröder HF, Cramer C, Mauer C, Selke D: Vergleichende Bewertung von oxidativen und adsorptiven Verfahren zur Elimination von Arzneimitteln - Praxisrelevanz und Anwendungsgrenzen. Gewässerschutz: Wasser - Abwasser, Aachen; 2009. 23/1-23/13.

4. Stalter D, Magdeburg A, Oehlmann J: Comparative toxicity assessment of ozone and activated carbon treated sewage effluents using an in vivo test battery. Wat Res 2010, 44(8):2610-2620.

5. Schrank SG, Bieling U, José HJ, Moreira RFPM, Schröder HF: Generation of endocrine disruptor compounds during ozone treatment of tannery wastewater confirmed by biological effect analysis and substance specific analysis. Wat Sci Technol 2009, 59(1):31-38.

6. Margot J, Magnet A, Thonney D, Chevre N, De Alencastro F, Rossi L: Traitement de micropullutants dans les eaux usées. Rapport final sur les essaies pilotes a la step de vidy à Lausanne. EAWAG $2011: 118$. EPFL-report-163236. http://infoscience.epfl.ch/record/163236/files/ Rapport_final_STEP_Vidy.pdf.

7. Steinmetz H, Dittmer U: Regenwasserbehandlung gestern, heute - und morgen? Stuttgarter Berichte zur Siedlungswasserwirtschaft 2010, 204:7-14.

8. Brunner PG: Bodenfilter zur Regenwasserbehandlung im Misch- und Trennsystem. Report LFU Karlsruhe; 2002. http://www.lubw.badenwuerttemberg.de/servlet/is/6638/

9. Waldhoff A: Hygienisierung von Mischwasser in Retentionsbodenfiltern (RBF). Schriftenreihe des Fachgebietes Siedlungswasserwirtschaft. University of Kassel 2008:306.

10. Triebskorn R, Adam S, Behrens A, Beier S, Böhmer J, Braunbeck T, Casper H, Dietze U, Gernhöfer M, Honnen W, Köhler HR, Körner W, Konradt J, Lehmann R, Luckenbach T, Oberemm A, Schwaiger J, Segner H, Strmac M, Schüürmann G, Siligato S, Traunspurger W: Establishing causality between pollution and effects at different levels of biological organization: The VALIMAR project. Hum Ecol Risk Ass 2003, 9(1):171-194.

11. Triebskorn R, Hetzenauer $\mathrm{H}$ : Micropollutants in three tributaries of Lake Constance, Argen, Schussen and Seefelder Aach: a literature review. (Mikroverunreinigungen in den drei Bodenseezufluessen Argen, Schussen und Seefelder Aach - eine Literaturstudie). Environ Sci Eur 2011, 24:8. http://www.enveurope.com/content/pdf/2190-4715-24-8.pdf.

12. DIN EN ISO 9308: Wasserbeschaffenheit - Nachweis und Zählung von Escherichia coli und coliformen Bakterien in Oberflächenwasser und Abwasser - Teil 3: Miniaturisiertes Verfahren durch Animpfen in Flüssigmedium (MPN-Verfahren). Berlin: Deutsches Institut für Normung e.V; 1999.

13. Bai S, Lung WS: Modeling sediment impact on the transport of fecal bacteria. Wat Res 2005, 39(20):5232-5240.

14. DIN 58940: Empfindlichkeitsprüfung von mikrobiellen Krankheitserregern gegen Chemotherapeutika. Berlin: Deutsches Institut für Normung e.V; 2011.

15. ISO: Water quality - Determination of the genotoxicity of water and waste water using the umu-tests. ISO Test Guideline 1999, ISO/FDIS 13829

16. ISO: Water quality - Determination of the genotoxicity of water and waste water - Salmonella/microsome fluctuation tests (Ames fluctuation test). ISO Test Guideline 2009, ISO/CD 11350.

17. Sørensen JG, Kristensen TN, Loeschcke V: The evolutionary and ecological role of heat shock proteins. Ecol Lett 2003, 6:1025-1037.

18. Köhler HR, Bartussek C, Eckwert H, Farian K, Gränzer S, Knigge T, Kunz N: The hepatic stress protein (hsp70) response to interacting abiotic parameters in fish exposed to various levels of pollution. J Aquat Ecosys Stress Recov 2001, 8:261-279.

19. Kaisarevic S, Hilscherová K, Weber R, Sundqvist KL, Tysklind M, Voncina E, Bobic S, Andric N, Pogrmic-Majkic K, Vojinovic-Miloradov M, Giesy JP, Kovacevic R: Characterization of dioxin-like contamination in soil and sediments from the "hot spot" area of petrochemical plant in Pancevo (Serbia). Env Sci Poll Res 2011, 18(4):677-686.

20. Wagner $\mathrm{M}$, Oehlmann J: Endocrine disruptors in bottled mineral water: Total estrogenic burden and migration from plastic bottles. Environ Sci Pollut Res 2009, 16:278-286.

21. Burke DM, Mayer RT: Ethoxyresorufin: Direct fluorimetric assay of a microsomal o-dealkylation which is preferentially inducible by 3-methylcholanthrene. Drug Metab Dispos 1974, 2(6):583-588.

22. OECD: Lemna sp. growth inhibition test. OECD Guideline for the Testing of Chemicals 2006, 221

23. Durieux EDH, Farver TB, Fitzgerald PS, Eder KJ, Ostrach DJ: Natural factors to consider when using acetylcholinesterase activity as neurotoxicity 
biomarker in Young-Of-Year striped bass (Morone saxatilis). Fish Physiol Biochem 2011, 37:21-29.

24. Rault M, Collange B, Mazzia C, Capowiez Y: Dynamics of acetylcholinesterase activity recovery in two earthworm species following exposure to ethyl-parathion. Soil Biol Biochem 2008, 40:3086-3091.

25. Triebskorn R, Telcean I, Casper H, Farkas A, Sandu C, Stan G, Colarescu G, Dori T, Köhler HR: Monitoring Pollution in River Mures, Romania, Part II: Metal accumulation and histopathology in fish. Env Monitor Ass 2008, 141(1-3):177-188.

26. Schirling M, Jungmann $D$, Ladewig V, Ludwichowski KU, Nagel R, Köhler HR, Triebskorn R: Bisphenol A in artificial indoor streams: Il. Stress response and gonad histology in Gammarus fossarum (Amphipoda). Ecotoxicology 2006, 15(2):143-156.

27. Luckenbach $T$, Kilian $M$, Triebskorn $R$, Oberemm A: Fish early life stage tests as a tool to assess embryotoxic potentials in small streams. J. Aquat. Ecosys Stress Recov 2001, 8:355-370.

28. Nagel $R$, Dar T: The embryo test with the zebrafish (Danio rerio) - a general model in ecotoxicology and toxicology. ALTEX 2002, 19:38-48.

29. OECD: Sediment-water Lumbriculus toxicity test using spiked sediment. OECD Guideline for the Testing of Chemicals 2007, 225.

30. Meier C, Haase P, Rolauffs P, Schindehütte K, Schöll F, Sundermann A, Hering D: Methodisches Handbuch Fließgewässerbewertung zur Untersuchung und Bewertung von Fließgewässern auf der Basis des Makrozoobenthos vor dem Hintergrund der EG Wasserrahmenrichtlinie; 2006. http://www.fliessgewaesserbewertung.de.

31. Jarosova B, Blaha L, Vrana B, Randak T, Grabic R, Giesy JP, Hilscherová K: Changes in concentrations of hydrophilic organic contaminants and of endocrine-disrupting potential downstream of small communities located adjacent to headwaters. Env Int 2012, 45:22-31.

32. Pavlíková N, Bláhová L, Klán P, Bathulac SR, Sklenár V, Giesy JP, Bláha L: Enantioselective effects of alpha-hexachlorocyclohexane $(\mathrm{HCH})$ isomers on androgen receptor activity in vitro. Chemosphere 2012, 86(1):65-69.

33. Soto AM, Sonnenschein C, Chung KL, Fernandez MF, Olea N, Serrano FO: The E-Screen assay as a tool to identify estrogens: an update on estrogenic environmental pollutants. Environ Health Perspect 1995, 103:113-122.

34. Körner W, Hanf V, Schuller W, Kempter C, Metzger J, Hagenmaier H: Development of a sensitive E-screen assay for quantitative analysis of estrogenic activity in municipal sewage plant effluents. Sci Total Environ 1999, 225:33-48

35. Schultis T: Detection of estrogenic activity of environmental samples and pure compounds using biological test systems - development and comparison of in vitro assays. Dissertation: University of Stuttgart; 2005.

36. OECD: Detailed review paper (DRP) on molluscs life-cycle toxicity testing. OECD Series on Testing and Assessment 2010, 121

37. Burki R, Vermeirssen E, Körner $O$, Joris C, Burkhardt-Holm P, Segner $H$ : Assessment of estrogenic exposure in brown trout (Salmo trutta) in a Swiss midland river: integrated analysis of passive samplers, wild an caged fish, and vitellogenin mRNA and protein. Environ Toxicol Chem 2006, 25:2077-2086.

38. Stalter D, Magdeburg A, Weil M, Knacker T, Oehlmann J: Toxication or detoxication? In vivo toxicity assessment of ozonation as advanced wastewater treatment with the rainbow trout. Wat Res 2010, 44:439-448.

39. Kang IJ, Yokota H, Oshima Y, Tsuruda Y, Shimasaki Y, Honjo T: The effects of methyltestosterone on the sexual development and reproduction of adult medaka (Oryzias latipes). Aquat Toxicol 2008, 87:37-46.

40. Watts MM, Pascoe D, Carroll K: Population responses of the freshwater amphipod Gammarus pulex (L.) to an environmental estrogen, 17a-ethinylestradiol. Env Toxicol Chem 2002, 21(2):445-450.

41. Burnham KP, Anderson DR: Model selection and multimodel inference: a practical information-theoretical approach. New York: Springer; 2002.

42. Burnham KP, Anderson DR: Multimodel inference: understanding AIC and BIC in model selection. Sociological Methods in Res 2004, 33:261-304.
43. Anderson DR, Burnham KP, Thompson WL: Null hypothesis testing: Problems, prevalence, and an alternative. J Wild Management 2000, 64:912-923

44. Huckele S, Track T: Risk Management of Emerging Compounds and Pathogens in the Water Cycle (RiSKWa). Env Sci Eur 2012, MS ID: 6814121638173597.

doi:10.1186/2190-4715-25-2

Cite this article as: Triebskorn et al: SchussenAktivplus: reduction of micropollutants and of potentially pathogenic bacteria for further water quality improvement of the river Schussen, a tributary of Lake Constance, Germany. Environmental Sciences Europe 2013 25:2.

\section{Submit your manuscript to a SpringerOpen ${ }^{\circ}$ journal and benefit from:}

- Convenient online submission

- Rigorous peer review

- Immediate publication on acceptance

- Open access: articles freely available online

- High visibility within the field

- Retaining the copyright to your article

Submit your next manuscript at $\gg$ springeropen.com 